\title{
The Effects of Protein Energy Malnutrition (PEM) on Sperm Quality and Spermatogenesis of Male Rats Injected by Testosterone Enanthate ${ }^{+)}$
}

Eliza*, N. Moeloek**, N. Suhana**, S. Sri Sukmaniah***

\begin{abstract}
Abstrak
Telah diketahui, bahwa penyuntikan testosteron enantat (TE) kepada individu jantan dapat menyebabían azoopermia; namun sampai sekarang belum diketahui apakah akibat penyuntikan TE tersebut dipengaruhi oleh faktor makanan. Data WHO ${ }^{5}$ dan Waites ${ }^{6}$ memperlihatkan bahwa orang Kaukasia dan orang Mongolia reaksinya berbeda terhadap penyuntikan TE (pada orang Kaukasia hanya $50 \%$ menyebabkan azoospermia, sedangkan pada orang Mongolia menyebabkan $90 \%$ azoospermia). Diduga perbedaan tersebut disebabkan karena perbedaan dalam pola makanannya. Penelitian ini dilakukan untuk mengetahui pengaruh diet rendah enersi protein (protein energy malnutrition $=P E M$ ) dikombinasikan dengan penyuntikan TE terhadap kualitas sperma dan spermatogenesis tikus putih. Diduga bahwa penyuntikan $T E 1 \mathrm{mg} /$ minggu selama 8 minggu kepada tikus PEM akan menyebabkan penurunan kualitas spermatozoa maupun spermatogenesis. Kesimpulan yang diperoleh dalam penelitian ini adalah: konsentrasi sperma, morfologinormal sperma dan viabilitas sperma menurun, baik pada kelompok diet normal maupun pada kelompok diet rendah kalori protein; namun tidak ada perbedaan antara kedua kelompok diet tersebut. Berat testis, diameter testis, diameter tubulus seminiferus, jumlah spermatogonium-A dan jumlah spermatosit pakhiten juga menurun baik pada kelompok diet normal, maupun pada kelompok diet rendah enersi protein, tetapi pada kelompok diet rendah enersi protein lebih rendah jika dibandingkan dengan kelompok diet normal.
\end{abstract}

\begin{abstract}
The relationship of testosterone enanthate (TE) with azoospermia has been confirmed, but it is still not known whether its effect is also influenced by nutritional factor. Data of WHO ${ }^{5}$ and Waites ${ }^{6}$ showed that Caucasian and Mongolian men response differently to TE. It has been suggested that the difference in their eating pattern might cause higher susceptibility of the Mongolian to TE (90\% azoospermia) compared to the Caucasian (only 50\% azoospermia). This research was conducted to investigate the combination of protein energy malnutrition (PEM) and TE injection on sperm quality and spermatogenesis of albino male rats. It is hypothesized that PEM male rats will show lower sperm quality and sperm quantity after injected by $1 \mathrm{mg} T E$ once a week for eight weeks. The results of this study can be concluded that, sperm concentration, normal sperm morphology and sperm viability were decreased, in both normal diet and PEM animal after TE injection; nevertheless there was no difference between the two groups. Testis weight, diameter of the testis, diameter of the seminiferous tubule, the number of $A$-spermatogonium, and the number of pachytene spermatocyte were decreased in both normal diet and PEM animal after TE injection; but there was a difference between normal diet animals and PEM animals, being lower in PEM animals.
\end{abstract}

Keywords: Protein energy malnutrion, Testosterone Enanthate, Sperm Quality, Spermatogenesis, Rats

Concern over the rapidly growing world's population has stimulated andrologist to find effective, safe, and reversible contraceptive substances for men.

\footnotetext{
+) Supported by The Project of Research Team URGE (University Research For Graduate Education) No.: 023/HTPP/URGE I 995. Department of Education \& Culture, Directorate General of Higher Education

* Department of Biology, Faculty of Medicine, University of Andalas, Sumatra (Ex Student of Biomedical Post Graduate Program. University of Indonesia).

** Department of Biology, Faculty of Medicine, University of Indonesia, Jakarta.

*** Deparment of Nutrition, Faculty of Medicine, University of Indonesia. Jakaria
}

Nowadays, medical treatments involving the use of contraceptive pills are widely applied in the family planning program. Ideally, such contraceptive substances should have reversible capacity to inhibit spermatogenesis without effecting libido and sexual behavior. ${ }^{1}$

Hormone and anti-hormone that can impede the production of sperms by interfering with the activity of hypothalamus-hypophysis-testis are basically useful as birth control. ${ }^{2}$ To interrupt spermatogenesis at the hypothalamus level, for example, a substance that inhibits the production of Gonadotropin Releasing Hormone $(\mathrm{GnRH})$ is required. GnRH is a peptide hor- 
mone secreted from hypothalamus, stimulates the synthesis and release of LH (luteinizing hormone) and FSH (follicle-stimulating hormone). Both LH and FSH are produced by hypophysis; in men LH stimulates the production of testosterone by the Leydig cell within the testis, while FSH stimulates the production of $\mathrm{ABP}$ (androgen binding protein) by the Sertoli cell of the testis. Both testosterone and ABP have very important role in the process of spermatogenesis. But the testosterone in high concentration decreases the production of LH and FSH directly.

On the other hand, at the hyphophysis level hormone with a direct influence to the process is more needed. Of various hormone contained in contraceptive pills, combination of TE (testosterone enanthate) and DMPA (depot medroxy progesterone acetate) has been shown to be very effective in causing azoospermia or oligospermia. ${ }^{3}$ Fertile males treated by those hormones combination show reduced concentration of sperm, normal shape of sperm, and sperm motility. In addition, the treatment also reduces the integrity of sperm membrane so that penetration to cervix is hampered. ${ }^{4}$

Although the relationship of TE with azoospermia has been confirmed, it is still not known whether its effect is also influenced by nutritional factors. Data of $\mathrm{WHO}^{5}$ and Waites ${ }^{6}$ showed that Caucasian and Mongolian men response differently to TE. It has been suggested that the different in their eating pattern might cause higher susceptibility of the Mongolian to TE (90\% affected) compared to the Caucasian (only $50 \%$ affected). According to Hamilton and Bronson ${ }^{7}$, and Vawda and Mandlevana, ${ }^{8}$ protein deficiency in male rats can reduce their hyphofisis activities. Consequently, the production of hypophysis controlled hormone, such as FSH and LH, which are important in the spermatogenesis, will be disturbed.

Another research showed that lower concentration of androgen binding protein (ABP) is detected in blood plasm of male rat offsprings that have experienced protein deficiency. ${ }^{9}$ The presence of ABP in blood is necessary for transporting the androgen to germ cells, so that spermatogenesis can be induced. However, protein deficiency reduces the hypothalamus activity, that in turn affecting the production of ABP.

This research is conducted to investigate the effect of TE injection and malnutrition (protein energy malnutrition $=$ PEM) to sperm quality and spermatogenesis of albino male rats. It is hypothesized that PEM male rats injected with $1 \mathrm{mg}$ TE once a week for eight weeks will show lower sperm quality and quantity. The quality of sperm is qualitatively determined by its concentration, shape or morphology, and viability. In addition to those informations, data on testis weight, its diameter, diameter of seminiferous tubule, the number of A-spermatogonium and the number of pachytene spermatocyte/tubule, will also be evaluated.

\section{MATERIALS AND METHOD}

Animals used in this research were male albino rat strain LMR (Lembaga Makanan Rakyat) (Wistar derived). The number of experimental animals were 36 , which were divided into two groups:

1. Group one, consists of 18 animals and was given food on ad libitum base for up to three months old, the animal weight of approximately between 150 $200 \mathrm{~g}($ Normal $=N)$

2. Group two, consists of 18 animals and was given a diet food to induce protein energy malnutrition; therefore, their weights were lower, around 60-70\% of normal animals (correspond to protein energy malnutrion $=P E M$ ).

Each group was divided into 3 subgroups:

- $\quad C$ (untreated control) animals $(n=6)$

- $T C$ (treated control = placebo control) animals $(n=$ 6) injected with $0.2 \mathrm{ml}$ solvent (wijen oil) once a week begining at 12 th week after birth.

- $T$ (treated) animals $(\mathrm{n}=6)$ injected with $1 \mathrm{mg}$ TE in $0.2 \mathrm{ml}$ solvent (wijen oil) once a week begining at 12 th week after birth.

\section{Timetable}

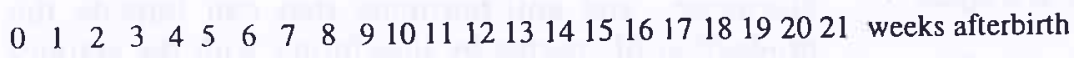

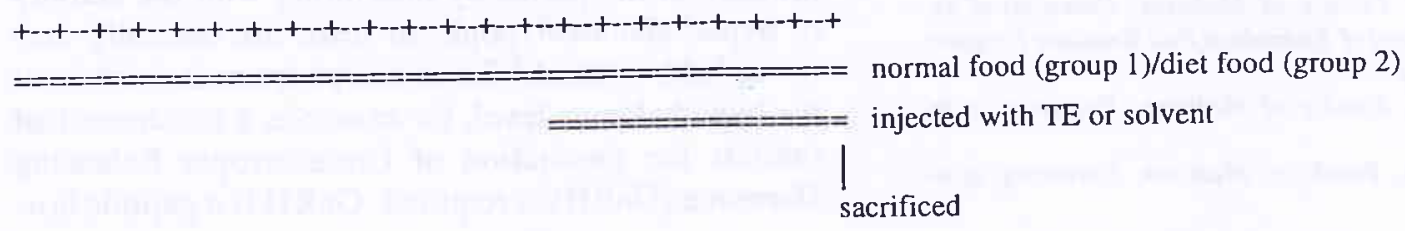


Animals were housed individually in $26 \times 21 \times 11 \mathrm{~cm}$ cages and they were floored by saw-dust to absorb urine. Testosterone enanthate (TE) and its solvent (wijen oil) was made by PT Schering Indonesia. The food was prepared in the Diponegoro unit of Nutrition of the Ministry of Health Office. At the end of the treatment (21 weeks afterbirth) all animals were sacrificed; both vas deferenses were excised and place in petri dish containing $0.25 \mathrm{ml} 0.85 \% \mathrm{NaCl}$. Both testis were also excised, weighted and then fixed in Bouin's solution then processed for histological preparation and evaluation.

The parameters evaluated of sperm collected from vas deferens were: a) sperm concentration, b) sperm morphology, and c) sperm viability. The parameters evaluated from the testis were: d) the weight, e)testis diameter, f) seminiferous tubule diameter, g) the number of A-spermatogonium, and h) the number of pachytene-spermatocyte. A Randomized Block Design was used with two factors (Normal and PEM animal) and three steps (injected by TE, solvent oil and control). Data were normalized and homogenized before statistical techniques were applied. Factorial tests two by three were used to compare six different treatments. If distribution of the data were abnormal, then non-parametric statistics were used. ${ }^{10}$ Analysis of variance (ANOVA-test) and HST (Honest Significant Test) were applied to see the difference among elements.

\section{RESULTS}

The results of parameters evaluated are as follows:

\section{Sperm concentration (vas deferens)}

Mean and SD of sperm concentration (million/ml) of normal $(\mathrm{N})$ and protein energy malnutrition (PEM) rats injected with testosterone enanthate (TE), is depicted in Figure 1.

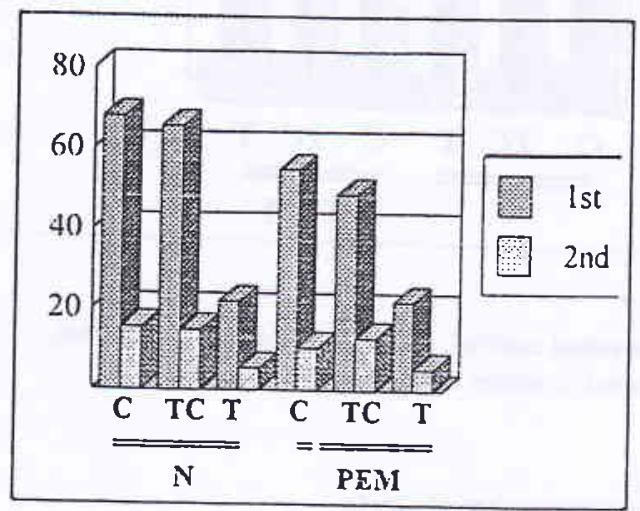

Figure I.

$C=$ untreated control; $T C=$ placebo/treated control; $T=$ treated, injected with $T E$

\section{Sperm morphology (Normal head sperm)}

Mean and SD of normal head sperm (\%) of normal and protein energy malnutrition (PEM) rats injected with TE, is depicted in Figure 2.

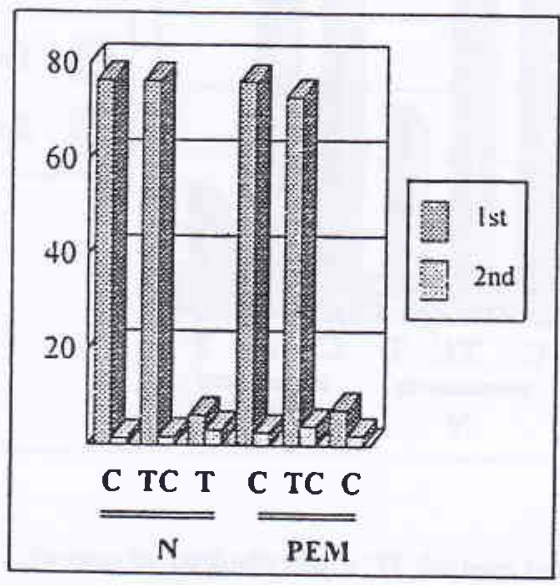

Figure 2.

$C=$ untreated control; $T C=$ placebo/treated control; $T=$ treated, injected with $T E$

\section{Sperm viability}

Mean and SD of sperm viability (\%) of normal and protein energy malnutrition (PEM) rats injected with TE, is depicted in Figure 3.

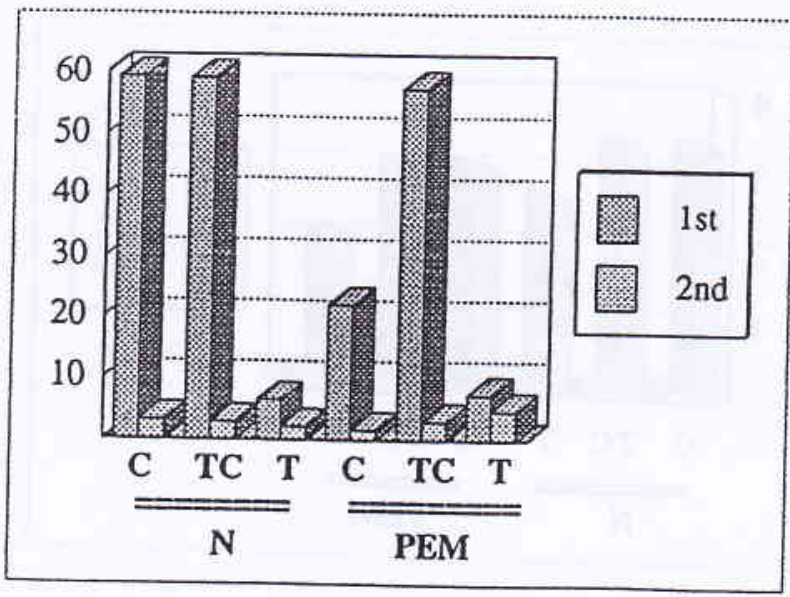

Figure 3.

$C=$ untreated control; $T C=$ placebo/treated control;

$T=$ treated, injected with $T E$.

\section{Testis weight}

Mean and SD of testis weight (mg) of normal and protein energy malnutrition (PEM) rats injected with TE, is depicted in Figure 4. 


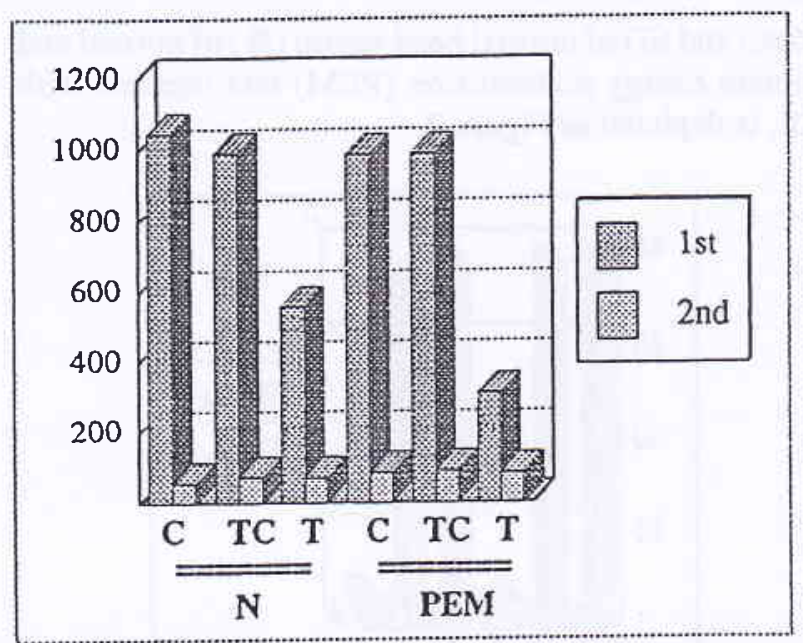

Figure 4.

$C=$ untreated control $; T C=$ placebo/treated control; $T=$ treated, injected with $T E$.

\section{Testis diameter}

Mean and SD of testis diameter $(\mathrm{cm})$ of normal and protein energy malnutrition (PEM) rats injected with TE, is depicted in Figure 5.

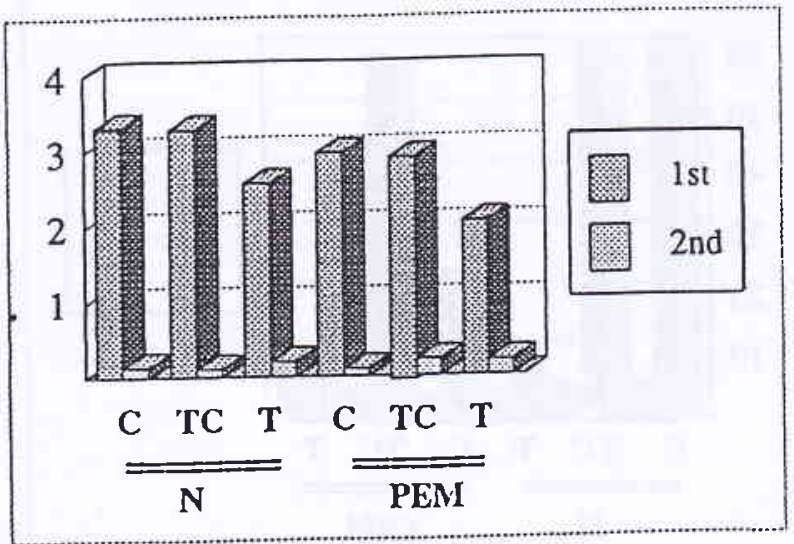

Figure 5.

$C=$ untreated control; $T C=$ placebo/treated control;

$T=$ treated, injected with $T E$.

\section{Seminiferous tubule diameter}

Mean and SD of seminiferous tubule diameter $(\mu \mathrm{m})$ of normal and protein energy malnutrition (PEM) rats injected with TE, is depicted in Figure 6.

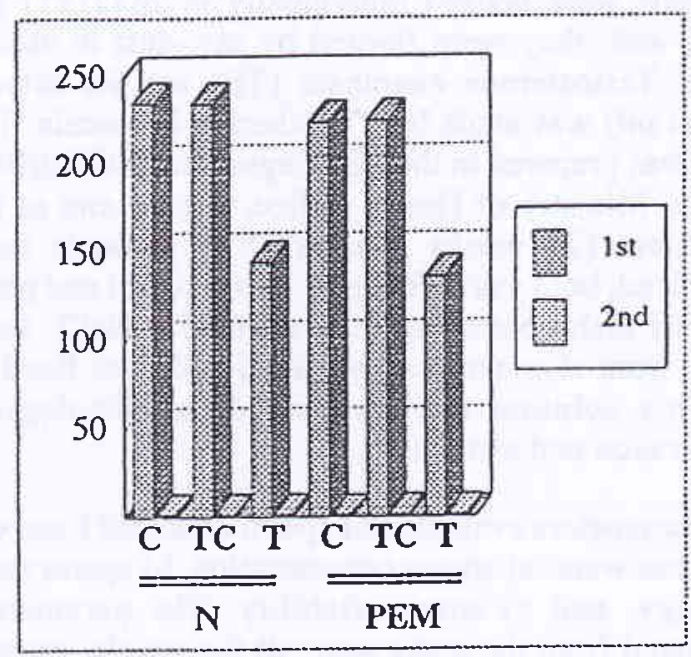

Figure 6.

$C=$ untreated control; $T C=$ placebo/treated control; $T=$ treated, injected with $T E$.

\section{A-Spermatogonium}

Mean and SD of A-spermatogonium number/tubule of normal and protein energy malnutrition (PEM) rats injected with TE, is depicted in Figure 7.

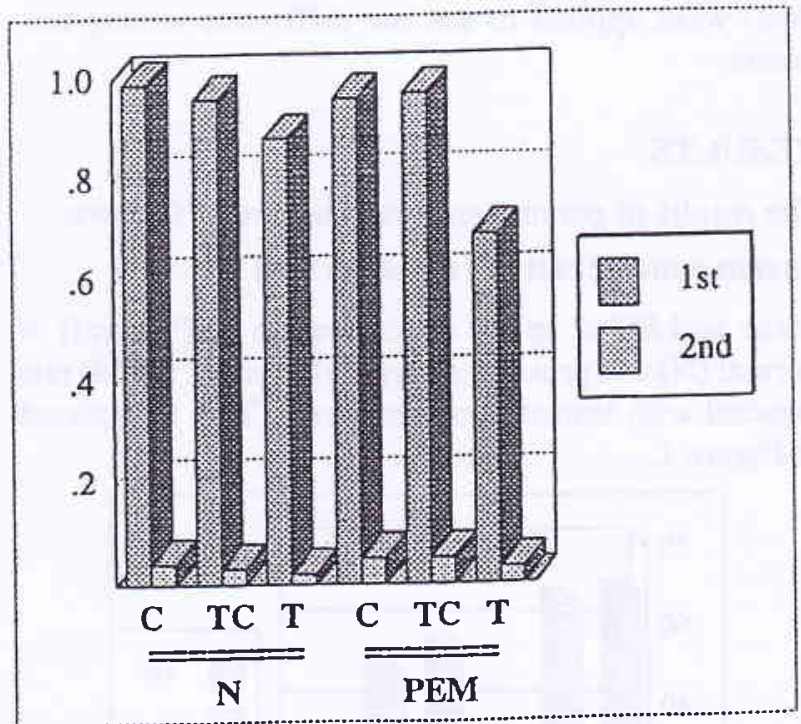

Figure 7.

$C=$ untreated control; $T C=$ placebo/treated control;

$T=$ treated, injected with $T E$.

\section{Pachytene spermatocyte}

Mean and SD of pachytene spermatocyte number/ tubule of normal and protein energy malnutrition (PEM) rats injected with TE is depicted in Figure 8. 


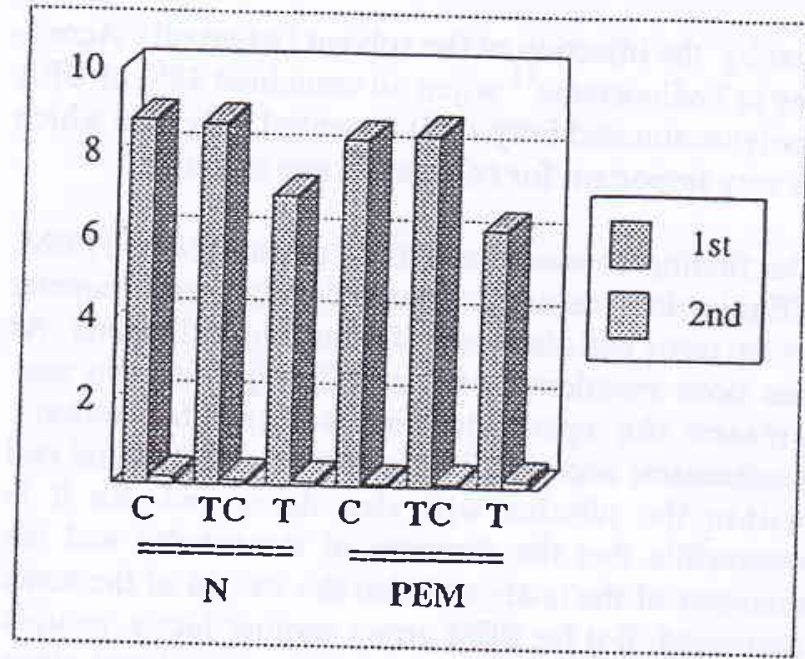

Figure 8.

$C=$ untreated control; $T C=$ placebo/treated control; $T=$ treated, injected with $T E$.

\section{The Statistical Analysis}

Distribution and Homogeinity of data

Before analysis of variance (ANOVA) test was carried out, normality data were tested using normality and homogenity test. Data on sperm concentration, weight of albino male testis, diameter of albino testis, and diameter of tubulus seminiferous were distributed nor$\mathrm{mal}$ and homogen. Some characters were distributed normal but were not homogen such as sperm viability and head shape of sperm. Conversely, data on A-spermatogonium and pachytene spermatocyte were distributed abnormal but homogen. Those abnormal and not homogen characters were transformed using Arcsin square root $x$, before ANOVA and Honest significance test were applied.

\section{Sperm concentration}

The results of the analysis of variance (ANOVA) test on sperm concentration show that both in normal $(\mathrm{N})$ and protein energy malnutrition (PEM) animals TE injection declined the sperm concentration significantly $(\mathrm{P}<0.01)$ compared to the uninjected and placebo control. There was no difference of the sperm concentration $(P>0.05)$ between TE injected PEM and TE injected normal animals.

\section{Sperm morphology}

ANOVA test on the sperm morphology shows that both in normal $(\mathrm{N})$ and protein energy malnutrition (PEM) animals TE injection declined the normal head sperm significantly $(\mathrm{P}<0.01)$ compared to the uninjected and placebo control. There was no difference of the sperm concentration $(P>0.05)$ between $T E$ injected PEM and TE injected normal animals.

\section{Sperm viability}

ANOVA test for sperm viability shows that both in normal $(\mathrm{N})$ and protein energy malnutrition (PEM) animals TE injection declined the sperm concentration significantly $(\mathrm{P}<0.01)$ compared to the uninjected and placebo control. There was no difference of the sperm concenration $(P>0.05)$ between TE injected PEM and TE injected normal animals.

The viability of normal uninjected control dropped significantly $(\mathrm{P}<0.01)$, compared to the normal control and placebo control of normal $(\mathrm{N})$ animals as well as to the placebo control of PEM animals.

\section{Testis weight}

ANOVA test for testis weight showed that both in normal $(\mathrm{N})$ and protein energy malnutrition (PEM) animals TE injection declined the testis weight significantly $(P<0.01)$ compared to the uninjected and placebo control. The testis weight dropped significantly $(\mathrm{P}<0.01)$ in $\mathrm{TE}$ injected PEM compared to TE injected normal animals.

\section{Testis diameter}

ANOVA test for testis diameter shows that both in normal $(\mathrm{N})$ and protein energy malnutrition (PEM) animals TE injection declined the testis diameter significantly $(\mathrm{P}<0.01)$ compared to the uninjected and placebo control. The testis diameter dropped significantly $(\mathrm{P}<0.01)$ in TE injected PEM compared to TE injected normal animals.

\section{Seminiferous tubule diameter}

ANOVA test shows that both in normal $(\mathrm{N})$ and protein energy malnutrition (PEM) animals TE injection declined the seminiferous tubule diameter significantly $(P<0.01)$ compared to the uninjected and placebo control. The diameter of tubule dropped significantly $(\mathrm{P}<0.01)$ in TE injected PEM compared to TE injected normal animals.

\section{A-spermatogonium}

ANOVA test shows that both in normal $(\mathrm{N})$ and protein energy malnutrition (PEM) animals TE injection declined the number of A-spermatogonium significantly $(P<0.01)$ compared to the uninjected and placebo control. The number of A-spermatogonium dropped significantly $(\mathrm{P}<0.01)$ in TE injected PEM compared to TE injected normal animals. 


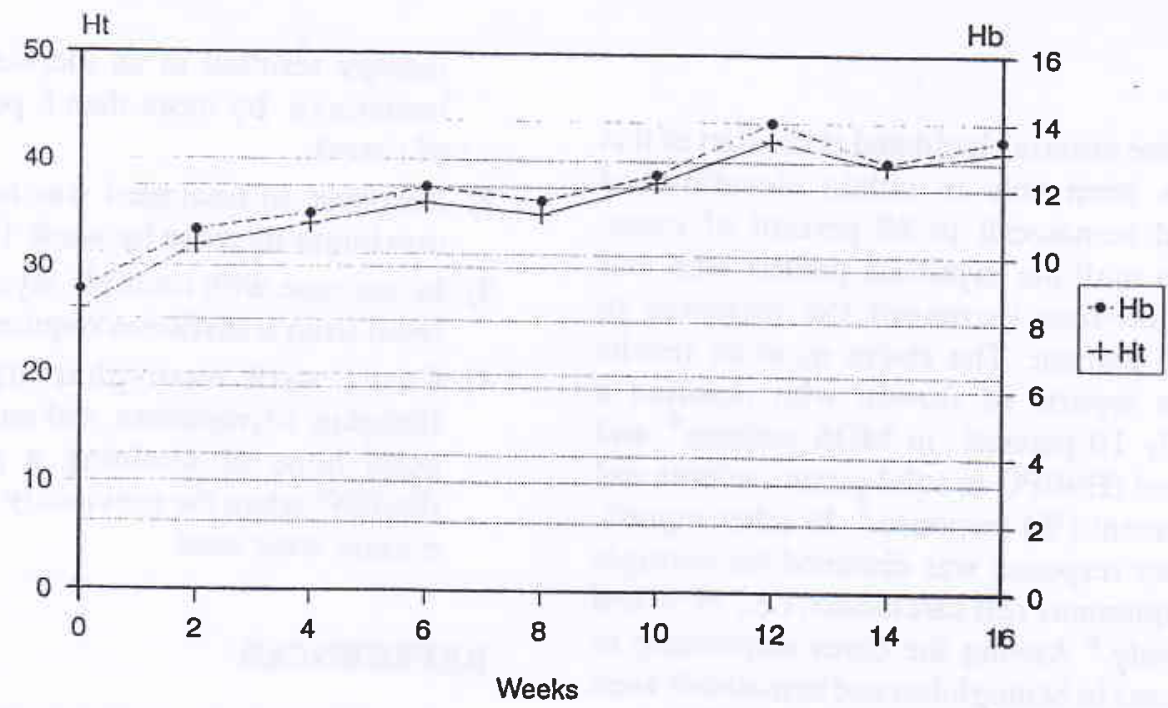

Figure 4. Case no. 4, male, 62 years old, Multiple Myeloma

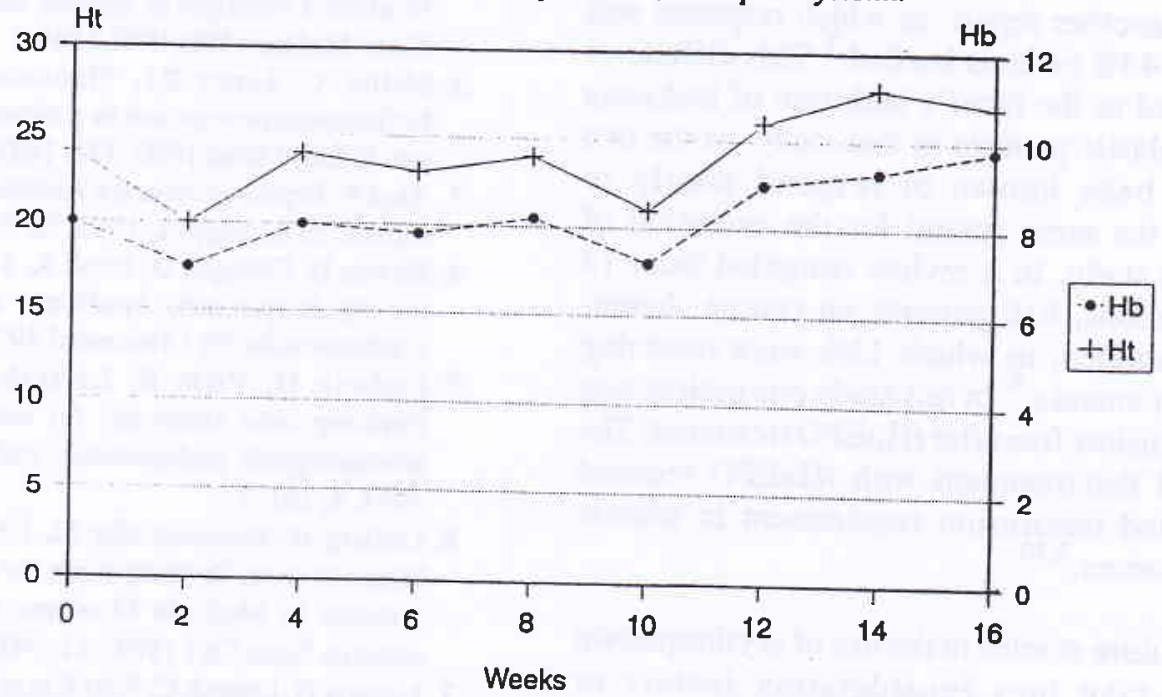

Figure 5. Case no. 5, male, 68 years old, Multiple Myeloma

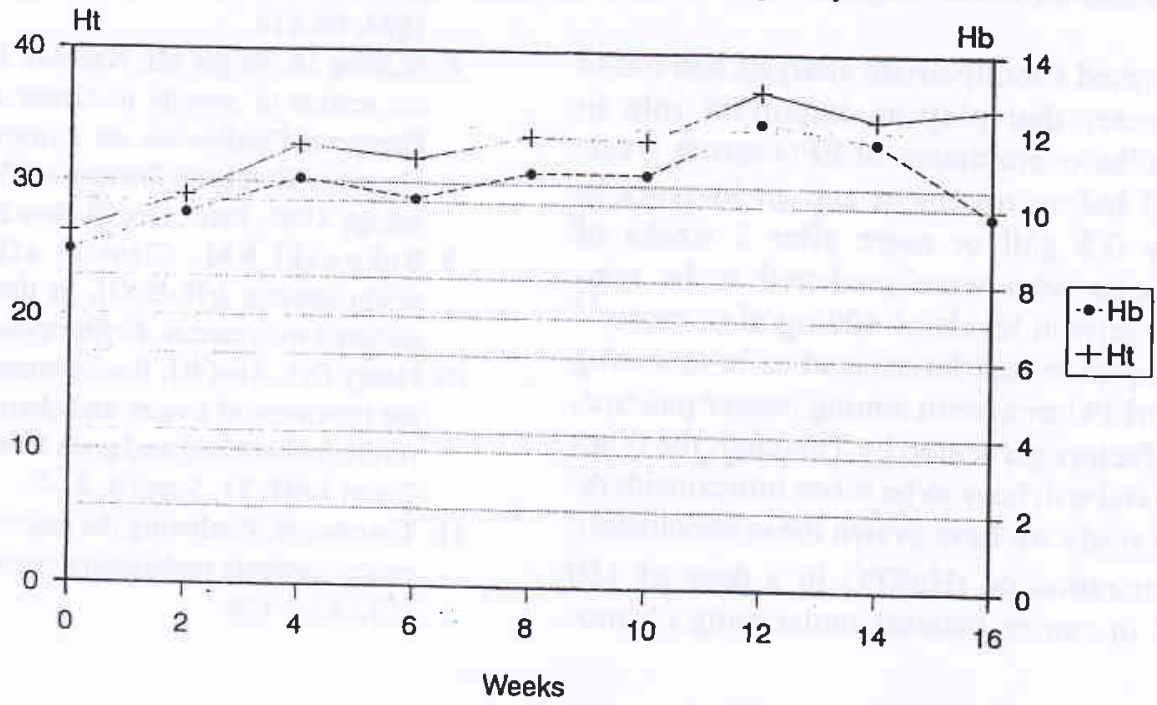

Figure 6. Mean $\mathrm{Hb}, \mathrm{Ht}$, from 5 cases 


\section{Pachytene spermatocyte}

ANOVA test showed that both in normal $(\mathrm{N})$ and protein energy malnutrition (PEM) animals TE injection declined the number of pachytene spermatocyte significantly $(\mathrm{P}<0.01)$ compared to the uninjected and placebo control. The number of pachytene spermatocyte declined significantly $(P<0.01)$ in TE injected PEM compared to TE injected normal animals.

\section{DISCUSSION}

The declining of sperm concentration after TE injection either on the normal $(\mathrm{N})$ and protein energy malnutrition (PEM) animals is very likely. This is due to a negative feedback of exogenous testosterone directly to the hypophysis which supresses the production of LH and FSH or may be through the hypothalamus so the production of RH-LH decreases and eventually the production of LH and FSH will also drop. In both cases, finally the process of spermatogenesis will be suppressed. Since there is no difference of sperm concentration between normal $(\mathrm{N})$ and protein energy malnutrition (PEM) animals, there is no interaction between TE injection and protein energy malnutrition on spermatogenesis, so the declining of sperm concentration in this experiment is solely due to the TE injection.

The same explanation is hold true also for sperm morphology, so the decreasing number of normal sperm morphology was due to the TE injection that hampered the process of organel cell development. Since there was no difference the number of normal sperm morphology between TE injected in both normal (N) and PEM animals, so it was very likely that the decreasing number of sperm morphology was due to the TE injection.

The same results and very likely also the mechanism were also found on the viability of the sperm in the sense that the number of viable sperm also declined after TE injection in both normal and PEM animals; this declining was also due to exogenous testosterone, because there was no interaction between TE injection and PEM.

The most interesting phenomenon is that the viability of sperm in the untreated control PEM animals also declined, although in the treated control of PEM animals did not. This is probably due to the calory deficiency; this deficience might be disrupt the cell membrane with the end result affected the viability. In the treated control of PEM, this deficience has been met by the injection of the solvent (wijen oil). Acording to Sediaoetama ${ }^{11}$ wijen oil contained $43 \%$ of UFA (polyunsaturated fatty acid), essential fatty acid which is very important for cell membrane integrity.

Our finding showed that both in normal (N) and PEM, TE injection caused decrease of weight and diameter of the testis and also seminiferous tubule diameter. As has been mentioned earlier, TE injection can suppressed the spermatogenesis through feedback mechanism; accordingly the number of germinal cell within the tubules will also decreased. So it is reasonable that the diameter of the tubules and the diameter of the testis and also the weight of the testis decreased. But for PEM group another factor, protein energy malnutrion ( $P E M$ ) should be considered, since there was a difference between TE injected treated PEM animals with the TE injected normal $(N)$ animals (significantly lower in PEM group), for all three parameters (testis weight, testis diameter and tubule diameter). The result of statistical analysis support such preposition, since there was positive interaction between factor TE injection and PEM.

According to Lermite and Tergui ${ }^{14}$ reported that nutritional status seem to be an additional factor regulating sex-steroid binding protein (SBP) level which may alter the percentage of SBP available for positive or negative feedback; the decline of SBP, results in the increasing concentration of free androgen in serum. Street et al., ${ }^{15}$ found that nonesterified fatty acids modify binding affinities of sex steroid hormone to $\mathrm{SBP}$ in vitro. Since in this experiment PEM group is undernourish, it is predicted that supply of fatty acid and protein is very limited; it follows by the availability of SBP in the blood, more over if the affinity to testosterone is also low, then the blood free testosterone increases sharply upon the introduction of exogenous testosterone; followed by stronger feedback mechanism in PEM group compared to nor$\mathrm{mal}(\mathrm{N})$ group. Thus, this condition will induce stronger suppression of spermatogenesis in PEM than in normal $(\mathrm{N})$ group.

The same explanation is hold true also for the number of A-spermatogonim and pachytene spermatocyte, so the decreasing number of both the germinal cells were due to the TE injection that hampered the proliferation during spermatogenesis. Since there was a difference between TE injected in normal $(\mathrm{N})$ and PEM animals concerning to the number of germinal cells, it was very likely that the decreasing number of A-spermatogonia and pachytene spermatocyte in PEM animals was due to the interaction between TE injection and PEM. 
The histological preparations of seminiferous tubules taken from normal (N) and PEM animals show the difference of the tubules diameter (Fig. 9 and Fig. 10).

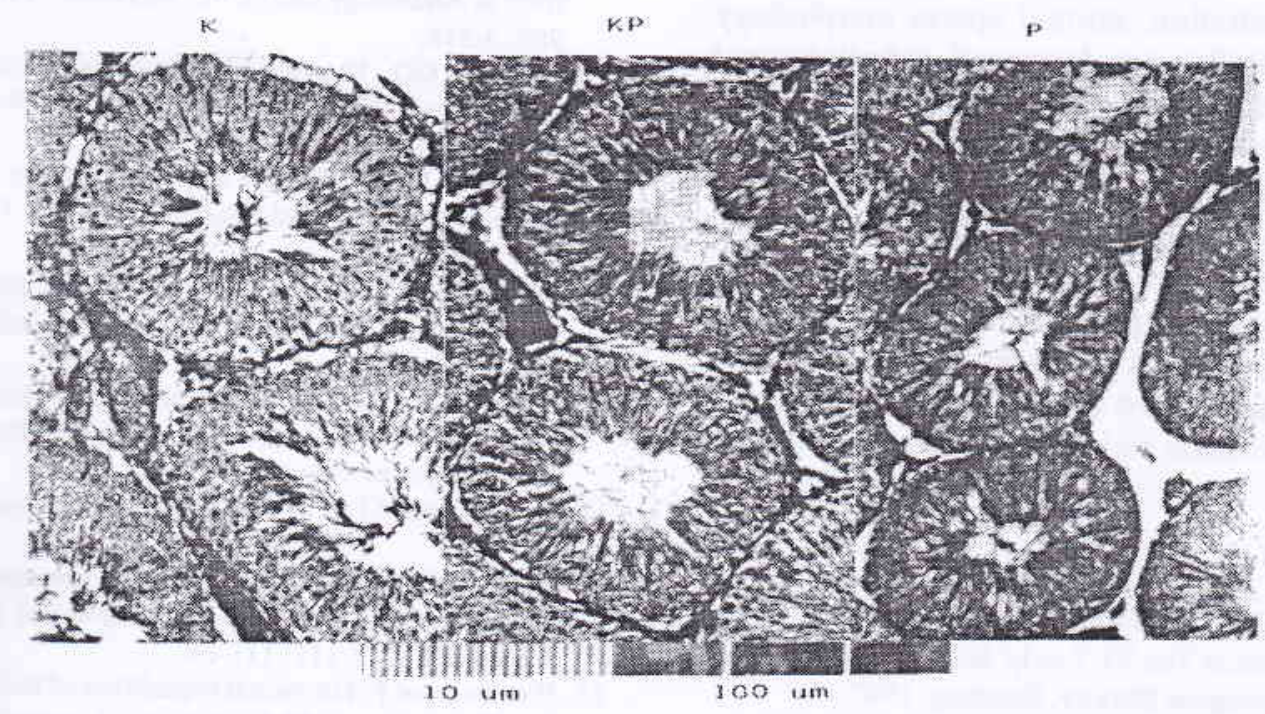

Figure 9. Histological preparation showing the seminiferous tubule of normal diet $(N)$ animal; $K(C)$, untreated control; KP (CT), treated/placebo control; $T(P)$, injected by TE. Compare the smaller tubule diameter of treated animal.

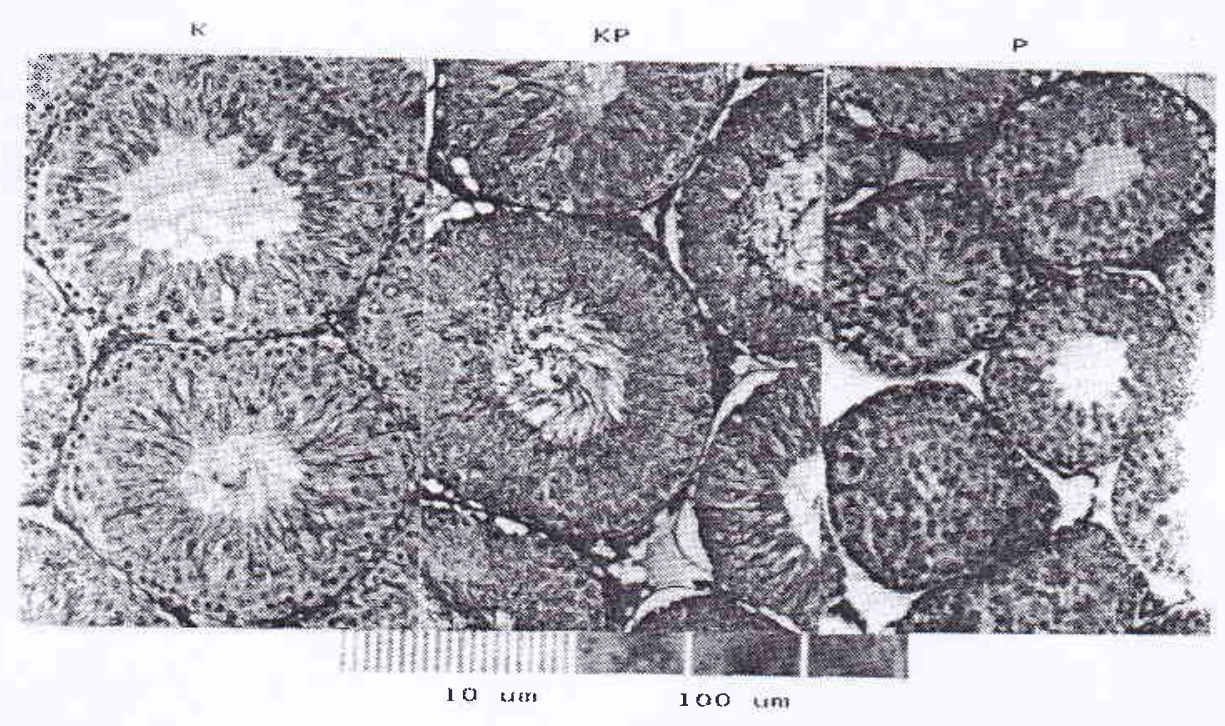

Figure 10. Histological preparation showing the seminiferous tubule of protein energy malnutrition (PEM) animal; $K(C)$, untreated control; $K P(C T)$, treated/placebo control; $T(P)$, injected by $T E$. Compare the smaller tubule diameter of treated animal. 


\section{CONCLUSION}

The effect of protein energy malnutrition (PEM) on sperm quality and spermatogenesis of male rats injected with TE, can be concluded as follow:

1. Sperm concentration, normal sperm morphology and sperm viability was decreased, in both normal diet and PEM animal; nevertheless there was no difference between treated normal diet animals and treated PEM animals.

2. Testis weight, diameter of the testis, diameter of the seminiferous tubule, the number of spermatogonium- $A$, and the number of pachytene spermatocyte decreased in both normal diet and PEM animal; but there was a difference between treated normal diet animals and treated PEM animals.

\section{REFERENCES}

1. Moeloek N. Kontrasepsi pria masa kini dan masa akan datang. Presented at The VI Yearly Scientific Meeting, Indonesian Andrological Society, Bandung, 1987.

2. Tadjudin MK. Cara keluarga berencana hormonal pada pria. Proceeding of National Kongres I, Indonesian Endocrinological Society, Jakarta, 1986;22-229.

3. Frick J, Danner Ch, Kunit G et al. Spermatogenesis in men treated with injection of mendroxyprogesterone acetate combined with testosterone enanthate. Int J Androl 1982; 24652.

4. Moeloek N. Penurunan kesuburan pria pada penyuntikan testosteron (TE) + DMPA dan 19 Nortestosteron heksiloksifenil propionat (19-NT) + DMPA. Dissertation, Faculty of Medicine University of Indonesia, Jakarta, 1991.
5. Word Health Organization. Contraceptive efficasy of testosterone induced azoospermia in normal men. Lancet, 1990; 336: 955-9.

6. Waites GMH. The research strategy of the WHO task force on methods for the regulation of male fertility. In: Perspectives in Andrology (Serio, M, ed), Raven Press, New York. $989 ; 3-516$

7. Hamilton GD, Bronson FH. Food restriction and reproductive development male and female mice and male rats.Am J Physiol 1986; 250: 370-6.

8. Vawda AL, Mandlevana JG. The effect of dietary protein deficiency on rat testicular function. Int $\mathbf{J}$ Androl 1980; 22:575-83

9. French FS, Ritzen EM. Androgen binding protein (ABP) in efferent duct fluid of rat testis. J Reprod Ferfil., 1973 32:479-83.

10. Nainggolan M. Experimental design (perencanaan dan pengerjaan percobaan). GIS Research Institute, Medan Branch, Medan, Sumatra, 1965.

11. Sediaoetama AD. Faktor gizi. Bharata Karya Aksara, Jakarta, 1985.

12. Clermont $Y$. Quantitative analysis of spermatogenesis of the rat : A Revised Model for the Renewal of Spermatogonia. Am J Anat 1972;111: 111-29.

13. Franchimont $P$. Hormonal requalition of testicular function. In : Regulation of Male Fertility. Cuningham GR, Sehell WB, Hafez ESE (eds). Martinus Nifhoff Publisher, London. 1980; 5-14.

14. Lermite $V$, Tergui M. Plasma sex sterojd binding protein in mature Heifers: Effect of the productive status, nutritional level, and porcine growth hormone, and tradiol-17ß treatment. Bio Rep 1991; 44:864-70.

15. Street C, Herry RJS, Al-Othman S, Chard T. Inhibition of binding of gonadal steroid to serum binding protein by non-esterified fatty acids: the influence of chain lenght and degree of unsaturation. Acta Endocrinol 1989;120:175-79. 


\section{Pachytene spermatocyte}

ANOVA test showed that both in normal $(\mathrm{N})$ and protein energy malnutrition (PEM) animals TE injection declined the number of pachytene spermatocyte significantly $(\mathrm{P}<0.01)$ compared to the uninjected and placebo control. The number of pachytene spermatocyte declined significantly $(\mathrm{P}<0.01)$ in TE injected PEM compared to TE injected normal animals.

\section{DISCUSSION}

The declining of sperm concentration after TE injection either on the normal $(\mathrm{N})$ and protein energy malnutrition (PEM) animals is very likely. This is due to a negative feedback of exogenous testosterone directly to the hypophysis which supresses the production of LH and FSH or may be through the hypothalamus so the production of RH-LH decreases and eventually the production of LH and FSH will also drop. In both cases, finally the process of spermatogenesis will be suppressed. Since there is no difference of sperm concentration between normal $(\mathrm{N})$ and protein energy malnutrition (PEM) animals, there is no interaction between TE injection and protein energy malnutrition on spermatogenesis, so the declining of sperm concentration in this experiment is solely due to the TE injection.

The same explanation is hold true also for sperm morphology, so the decreasing number of normal sperm morphology was due to the TE injection that hampered the process of organel cell development. Since there was no difference the number of normal sperm morphology between TE injected in both normal (N) and PEM animals, so it was very likely that the decreasing number of sperm morphology was due to the TE injection.

The same results and very likely also the mechanism were also found on the viability of the sperm in the sense that the number of viable sperm also declined after TE injection in both normal and PEM animals; this declining was also due to exogenous testosterone, because there was no interaction between TE injection and PEM.

The most interesting phenomenon is that the viability of sperm in the untreated control PEM animals also declined, although in the treated control of PEM animals did not. This is probably due to the calory deficiency; this deficience might be disrupt the cell membrane with the end result affected the viability. In the treated control of PEM, this deficience has been met by the injection of the solvent (wijen oil). Acording to Sediaoetama ${ }^{11}$ wijen oil contained $43 \%$ of UFA (polyunsaturated fatty acid), essential fatty acid which is very important for cell membrane integrity.

Our finding showed that both in normal $(N)$ and PEM, TE injection caused decrease of weight and diameter of the testis and also seminiferous tubule diameter. As has been mentioned earlier, TE injection can suppressed the spermatogenesis through feedback mechanism; accordingly the number of germinal cell within the tubules will also decreased. So it is reasonable that the diameter of the tubules and the diameter of the testis and also the weight of the testis decreased. But for PEM group another factor, protein energy malnutrion (PEM) should be considered, since there was a difference between TE injected treated PEM animals with the TE injected normal (N) animals (significantly lower in PEM group), for all three parameters (testis weight, testis diameter and tubule diameter). The result of statistical analysis support such preposition, since there was positive interaction between factor TE injection and PEM.

According to Lermite and Tergui ${ }^{14}$ reported that nutritional status seem to be an additional factor regulating sex-steroid binding protein (SBP) level which may alter the percentage of SBP available for positive or negative feedback; the decline of SBP, results in the increasing concentration of free androgen in serum. Street $e t$ al., ${ }^{15}$ found that nonesterified fatty acids modify binding affinities of sex steroid hormone to SBP in vitro. Since in this experiment PEM group is undernourish, it is predicted that supply of fatty acid and protein is very limited; it follows by the availability of SBP in the blood, more over if the affinity to testosterone is also low, then the blood free testosterone increases sharply upon the introduction of exogenous testosterone; followed by stronger feedback mechanism in PEM group compared to normal (N) group. Thus, this condition will induce stronger suppression of spermatogenesis in PEM than in normal $(\mathrm{N})$ group.

The same explanation is hold true also for the number of A-spermatogonim and pachytene spermatocyte, so the decreasing number of both the germinal cells were due to the TE injection that hampered the proliferation during spermatogenesis. Since there was a difference between TE injected in normal (N) and PEM animals concerning to the number of germinal cells, it was very likely that the decreasing number of A-spermatogonia and pachytene spermatocyte in PEM animals was due to the interaction between TE injection and PEM. 